\title{
El acceso al alto clero en el arzobispado de México 1680-1757
}

\author{
Rodolfo Aguirre \\ Universidad Autónoma de México \\ aguirre_rodolfo@hotmail.com
}

\begin{abstract}
Resumen
En este trabajo se analiza uno de los grupos organizados de clérigos del arzobispado de México, cuya presencia se sitúa en dos generaciones, entre 1680 y 1757. El autor se centra en la trayectoria de dos dignatarios eclesiásticos para demostrar que las relaciones y la integración a grupos o colectivos podían determinar el ingreso al cabildo catedralicio o la obtención de cargos eclesiásticos relevantes. José Torres Vergara y Francisco Rodríguez Navarijo no nacieron en familias poderosas y, sin embargo, llegaron a las cimas del poder. Su estrategia fue combinar méritos personales y buenas relaciones con grupos, corporaciones eclesiásticas y arzobispos; es decir, con la élite del arzobispado. La protección de padrinos o grupos poderosos no fue circunstancial sino el resultado de lazos familiares, de amistades o de relaciones formadas en el seno de las escuelas, los colegios o de la participación en la vida pública de la clerecía. Tales relaciones las podemos hallar en los clérigos que aspiraban a ingresar al cabildo catedralicio de México, que comúnmente formaban parte de un subgrupo o sector del clero.
\end{abstract}

Palabras clave: HISTORIA ECLESIÁSTICA, ARZOBISPADO DE MÉXICO, CORPORACIONES ECLESIÁSTICAS, FAMILIA, SIGLO XVII, SIGLO XVIII.

\begin{abstract}
This text analyze one of the groups of organized clergy in the archbishopric of Mexico along two generations, from 1680 to 1757 . The text centers on the trajectory of two clergy members in order to demonstrate that the relationship to or membership in groups or collectives could determine entry to the cathedral council or access to important ecclesiatical posts. José Torres Vergara and Francisco Rodríguez Navarijo were not born into into powerful families, and yet they reached powerful positions. Their strategy combined personal merit and good relationships with groups, ecclesiastical corporations, and archbishops, that is to say, with the elite of the archbishopric. Protection by patrons or powerful groups was not circumstantial. Rather, it was the result of kinship ties, friendships, or realtionships formed in schools, colleges or the participation of clergy members in public life. This sort of realtionships can be found amongst the
\end{abstract}


clergy members that aspired to enter the cathedral council of Mexico, and that commonly formed a subgroup or sector of the clergy.

Key words: CHURCH HISTORY, ARCHBISHOPRIC OF MEXICO, ECCLESIASTICAL CORPORATIONS, FAMILY, $17^{\mathrm{TH}}$ CENTURY, $18^{\mathrm{TH}}$ CENTURY.

\section{El clero secular del arzobispado de México hacia la primera mitad del siglo XVIII}

A inicios del siglo XVIII el clero secular del arzobispado de México estaba constituido por clérigos provenientes de varias capas sociales, desde criollos de diversos niveles de riqueza y educación, pasando por grupos mestizos integrados a alguna de las dos repúblicas formales, de indios y de españoles, hasta algunas docenas de la nobleza indígena ${ }^{1}$. La clerecía del arzobispado de México, considerada una de las más grandes de la Nueva España ${ }^{2}$, mostraba así el devenir del desarrollo de la sociedad novohispana en sus integrantes, constituyendo un conjunto heterogéneo en cuanto a su procedencia social, a su formación y a sus aspiraciones.

Desde la perspectiva de las actividades que desarrollaban, los clérigos muestran diferencias notables. Había un primer sector proveniente de las capas bajas, cuando mucho modestas, de la población novohispana, con grados académicos menores, sin recursos o interés por hacer carrera en México, anónimos la mayoría, cuya vida transcurrió en los desolados curatos rurales de la arquidiócesis ${ }^{3}$.

En la ciudad de México también existía un amplio sector de clérigos con un nivel de vida similar al rural, compuesto por personajes ocupados en bajos empleos, que durante su vida no habían hecho otra cosa sino sobrevivir. El bajo clero urbano se caracterizaba por desempeñar cargos inferiores durante toda su vida ${ }^{4}$. Un tercer sector, más afortunado, era el de los clérigos dedicados a servir capellanías ${ }^{5}$.

1 Rodolfo Aguirre Salvador, "Los caciques en las instituciones coloniales del período colonial tardío. Una primera aproximación”, en Actas del coloquio “Los derechos del hombre desde una perspectiva histórico-jurídica. 1808-1917” (México: UNAM), en prensa.

2 Aún no se han hecho estudios específicos sobre la población clerical del arzobispado de México. Datos importantes al respecto pueden encontrarse en el Archivo General de la Nación -en adelante AGN- (México), Bienes Nacionales, exp. 1271, leg. 1; Manuel José Rubio y Salinas, "Informe reservado de la clerecía del arzobispado de México” (febrero 1764), Archivo General de Indias -en adelante AGI-(Sevilla), México, 2547. También, David A. Brading, Una Iglesia asediada: el obispado de Michoacán, 1749-1810 (México: Fondo de Cultura Económica, 1994).

3 “Provisión de curatos del arzobispado de México. Relaciones de méritos de opositores”, AGN (México), Bienes Nacionales, 236, exp. 24.

4 AGN, Bienes, leg. 801, exp. 1 ó leg. 320, exp. 12, por ejemplo.

5 Manuel José Rubio y Salinas, “Informe reservado de la clerecía del arzobispado de México” (febrero 1764), AGI, México, 2547. 
El sector dominante del clero secular, o sea los miembros del cabildo catedralicio, los funcionarios de la curia arzobispal y los curas de la capital, era una minoría caracterizada por sus altos grados académicos, por tener recursos económicos suficientes, a veces cuantiosos, por provenir de familias distinguidas y bien relacionadas, por desempeñar una serie de actividades o líneas de ejercicio de su profesión y por estar integrada a corporaciones o grupos de poder que los ayudaban a llegar lejos en la carrera eclesiástica.

En el alto clero ninguno de sus miembros podía aspirar seriamente a tener éxito en su trayectoria pública o carrera de manera aislada o personal. Comparto la idea de que en el antiguo régimen los grupos o colectivos eran más importantes que los individuos $^{6}$. En un estudio anterior sobre las carreras eclesiásticas demostré que las trayectorias públicas no podían entenderse, de no ser en su forma más externa, sin tomar en cuenta los lazos y las relaciones con que contaban los clérigos para sus ascensos ${ }^{7}$. Igual de importante fue establecer que los cargos tenían varios significados para ellos: honor, ingresos económicos y poder de decidir y de influir en otros poderes públicos y corporaciones. Así, no fue difícil advertir que alrededor del cabildo catedralicio, de los curatos de la ciudad de México, de los funcionarios de los tribunales eclesiásticos, de los familiares de los arzobispos o de los catedráticos universitarios se conformaban grupos clientelares de cuya dinámica aún falta mucho por conocer ${ }^{8}$.

Aquí me propongo analizar uno de los grupos de clérigos del arzobispado de México, cuya presencia se sitúa en dos generaciones entre 1680 y 1757 . Para ello tomaré como eje la trayectoria de dos dignatarios eclesiásticos para demostrar que las relaciones y la integración a grupos o colectivos determinaban en gran medida el ingreso al cabildo catedralicio o la obtención de otros cargos eclesiásticos relevantes. José Torres Vergara y Francisco Rodríguez Navarijo no nacieron en familias poderosas y, sin embargo, llegaron a las cimas del poder en el arzobispado de México. ¿Cómo lo lograron? En esencia, combinando eficazmente méritos personales y estrategias

$6 \quad$ Paul Ganster, “La familia Gómez de Cervantes. Linaje y sociedad en el México colonial”, Historia Mexicana, núm. 122 (octubre-diciembre 1981). Francisco Chacón Jiménez, “Estructuración social y relaciones familiares en los grupos de poder castellanos en el antiguo régimen. Aproximación a una teoría y un método de trabajo”, en La pluma, la mitra y la espada. Estudios de historia institucional en la Edad Moderna, eds. Juan Luis Castellano, Jean Pierre Dedieu y María Victoria López-Cordón (Madrid: Universidad de Burdeos; Marcial Pons, 2000), 355-362.

7 Rodolfo Aguirre Salvador, El mérito y la estrategia. Clérigos, juristas y médicos en Nueva España (México: CESU; Plaza y Valdés, 2003).

8 La relación entre los cargos eclesiásticos y el ejercicio del poder en Nueva España no ha sido un tema recurrente en la historiografía, salvo algunos análisis que han privilegiado ante todo la relación iglesiamonarquía. Aunque se han hecho estudios muy valiosos de tipo prosopográfico (descriptivo) sobre algunos sectores clericales, que nos indican ciertos patrones externos de ese universo, aún faltan estudios profundos sobre la conformación de grupos internos y su participación en los juegos de poder y las prácticas políticas. Véase por ejemplo a Paul Ganster, "Miembros de los cabildos eclesiásticos y sus familias en Lima y la ciudad de México en el siglo XVIII”, en Familias novohispanas. Siglos XVI al XIX, coord. Pilar Gonzalbo (México: El Colegio de México, 1991). 
"relacionales” con grupos, corporaciones eclesiásticas y arzobispos, es decir, con la élite del arzobispado. La protección de padrinos o grupos poderosos no fue circunstancial sino el resultado de lazos familiares, de amistades o de relaciones formadas en el seno de las escuelas, los colegios o de la participación en la vida pública de la clerecía ${ }^{21}$. Tal tipo de relaciones las podemos hallar claramente en los candidatos a ingresar al cabildo catedralicio de México, quienes comúnmente formaban parte de un subgrupo o sector del clero.

La importancia de las carreras que aquí estudio reside, pues, en la capacidad de ambos personajes para ir construyendo las relaciones propicias para su arribo al alto clero. Igualmente, busco hacer una primera exploración de los grupos de poder existentes en el clero secular y de cómo estos se articulaban con otros poderes y autoridades haciendo uso de diferentes estrategias o vías. Las relaciones familiares, académicas y políticas dentro de la curia eclesiástica, del cabildo catedralicio, de los tribunales eclesiásticos o de la universidad son aquí las principales protagonistas.

\section{Los espacios de la clerecía en ascenso en la ciudad de México}

La ciudad de México, capital virreinal y sede del arzobispado, fue un lugar idóneo para hacer una carrera de altos vuelos en la Iglesia. En el siglo XVII se habían construido y consolidado sus principales instituciones así como los medios para su reproducción social. Pero no era fácil para los clérigos integrarse a ellas, pues debían contar con los méritos suficientes y las relaciones necesarias para tener éxito. Lo que más caracterizó al clero en ascenso de México, y de lo que dependía su fama y distinción, fue su capacidad de construir relaciones fundamentalmente con la jerarquía del arzobispado, cabildo y arzobispo, aunque también con otras instancias de gobierno y de poder, como el virrey, la audiencia, el ayuntamiento o el consulado de comerciantes ${ }^{10}$. Tal comunidad clerical estaba conformada por doctores clérigos, catedráticos y rectores de la universidad o los colegios, funcionarios de la curia o de la Inquisición y curas de la ciudad.

9 Magdalena Chocano, en su interesante libro La fortaleza docta. Élite letrada y dominación social en México colonial (siglos XVI-XVII) (Barcelona: Bellaterra, 2000), ha puesto al descubierto el sentido político que en Nueva España tenían los sermones, dedicatorias de tesis u oraciones fúnebres, entre otros actos públicos, para halagar o ganar protectores en los círculos letrados y eclesiásticos.

10 A medida que se avanza en el conocimiento de la clerecía de la época se hacen más nítidas las diferencias en cuanto al nivel de relaciones entre el clero rural y el enclavado en la ciudad de México. Retomando la propuesta de Katherine Faust, "Las redes sociales en las ciencias sociales y del comportamiento", en Análisis de redes. Aplicaciones en ciencias sociales, eds. Jorge Gil Mendieta y Samuel Schmidt (México: IIMAS; UNAM, 2002), 1-14, sobre saber diferenciar la densidad de relaciones de cada actor histórico, un ayudante de cura o un coadjutor alejado de la ciudad difícilmente tenía una presencia en las instituciones y dependencias eclesiásticas; sus nombres están ausentes de los memoriales de la universidad o de los arzobispos, cuando mucho aparecen los curas propietarios o algunos clérigos avecindados en la capital. 
Los méritos que iban logrando los clérigos eran muchas veces consecuencia de nuevas relaciones formadas en los exámenes para ganar las órdenes sacras, en los cursos, en las oposiciones a cátedras, curatos o canonjías, en la participación o asistencia de los eventos religiosos y sociales de la capital, pero también de lazos familiares, de amistad o clientelares. Cada nuevo clérigo asentado en la capital tenía ante sí todo un abanico de posibilidades para relacionarse con los grupos clericales bien instalados. En la época se usaba mucho el concepto de "buscar conveniencias"; es decir, amistades o recomendaciones que les posibilitaran el acceso a un cargo deseado. Si en la corte de Madrid se veía todos los días al "enjambre" de procuradores, letrados y clérigos buscando una merced real, en las dependencias eclesiásticas del arzobispado de México no era muy diferente, en el sentido de que los clérigos procuraban acercarse a los ya bien colocados para buscar su propio acomodo. De esa manera, la estrategia que muchos seguían era acrecentar sus lazos, tanto en cantidad como en calidad, esperando pronto integrarse a algún grupo bien definido, como cliente o "amigo", que le procurara acomodos y nuevos méritos. En el medio clerical del arzobispado se usaban términos como: "deudos”, “domésticos" o "válidos" para designar tal tipo de relaciones.

En el arzobispado de México existían varios espacios en donde se tejían día a día las relaciones, se protegían intereses y se consolidaban alianzas. Tales espacios igual funcionaban como punto de partida y como punto de culminación de trayectorias. Los más visibles y obvios eran aquellos corporativos, como el cabildo catedralicio o la congregación de San Pedro ${ }^{11}$. Otros eran grupos derivados de las instituciones, que sin ser exactamente una corporación, estaban unidos por la función que desempeñaban: funcionarios de la curia o del cabildo, curas, catedráticos o capellanes. Más difíciles de definir son los grupos más informales, menos obvios, pero a veces de mayor importancia que los anteriores debido a que sus intereses estaban íntimamente entrelazados como grupos de interés surgidos desde los espacios familiares o en el seno de las instituciones, pero que desbordaban sus límites. Difícilmente un clérigo nativo, con aspiraciones de ascenso, podía dejar de integrarse a alguno de esos ámbitos consagrados por el tiempo y las generaciones.

\section{De grupo familiar a clientelar}

Los casos de José Torres Vergara y Francisco Rodríguez Navarijo ilustran una continuidad de trayectorias clericales determinadas por relaciones y una presencia constante en tales espacios durante dos generaciones (1680-1757). Ellos se convirtieron

11 La congregación de San Pedro, espacio de distinción de los clérigos, más allá de la administración eclesiástica y de la academia, fue una comunidad sacerdotal en sus orígenes, que para el siglo XVIII también contaba con laicos poderosos, incluyendo a virreyes y oidores. De esta comunidad se sabe poco hasta la fecha pero sus cargos, honoríficos todos, aparecen constantemente en las relaciones de méritos del alto clero de México. Una visión introductoria de esta congregación es la de Asunción Lavrin, "La congregación de San Pedro -una cofradía urbana del México colonial- 1604-1730", Historia Mexicana XXIX, núm. 4 (1980): 562-601. 
en personajes centrales del clero gobernante del arzobispado. Crearon o fueron parte de grupos clientelares poderosos, capaces de obtener dignidades eclesiásticas y cargos en la curia, alcanzando poder y presencia. Al seguir sus pasos es posible comprobar la integración de grupos familiares a colectivos mayores mediante lazos de padrinazgo y de identidad corporativa, que a la larga podían convertirse en verdaderos grupos de poder.

\section{Las familias Torres Vergara y Rodríguez Navarijo}

Las familias eran el espacio de partida natural de los clérigos, no solo porque ellas los sustentaban, los educaban, los protegían y los recomendaban para iniciar su carrera, sino porque también los tíos o primos sacerdotes eran un modelo a seguir y, si estaban bien colocados, podían influir poderosamente en las carreras de los descendientes; más aún, los lazos familiares entre clérigos llegaban a determinar el ascenso al alto clero.

Torres Vergara y Rodríguez Navarijo tuvieron orígenes y trayectorias similares. Ambos nacidos en México, provenían de familias de nivel medio. Sus padres, sin ser parte de la élite gobernante, ocuparon cargos que los relacionaron con esta. El capitán Juan de Torres, padre de Torres Vergara, por ejemplo, fue regidor del ayuntamiento y al parecer un comerciante de mediana importancia ${ }^{12}$. En cuanto a Rodríguez Navarijo, su padre Juan Rodríguez Sánchez se había desempeñado como escribano público de Tlaxcala y es posible que se haya trasladado a México en busca de mejor fortuna al casarse con María de Navarijo, hija del cónsul del comercio, Felipe Navarijo. Francisco no dejó de referirse a sus padres como nobles, entendiendo este concepto más como sinónimo de españoles limpios y de vida honesta que como algún tipo de nobleza titulada ${ }^{13}$.

Torres y Rodríguez emparentaron entre sí cuando una hermana del primero, Bernarda, se casó con un tío del segundo, hijo del cónsul Felipe Navarijo ${ }^{14}$. Tal lazo de parentesco se transformó con el tiempo en un lazo afectivo-político muy fuerte. Aunque Rodríguez Navarijo no era el único sobrino que tuvo Torres, sí fue el más cercano.

12 En el caso de Torres y Vergara, sus padres fueron residentes de la ciudad de México a fines del siglo XVII. "Relación de méritos de José de Torres y Vergara, inserta en el expediente sobre la provisión de la cátedra de propiedad de Prima de Leyes de 1698”, AGN, Universidad, 101. Los hijos del capitán fueron José, Bernarda y Teresa. El único hijo del capitán Torres no siguió sus pasos sino que prefirió el camino de las letras y el sacerdocio, mientras que sus hermanas sí formaron familia.

13 "Provisión de la cátedra de Clementinas de 1706. Relación de méritos de Francisco Rodríguez Navarijo", AGN, Universidad, 95. En ella se lee al principio: "Es hijo legítimo de Juan Rodríguez Sánchez y doña María de Navarijo, cuya nobleza es notoria y consta de la información dada en la Real Universidad”.

14 El destino de las dos familias de clérigos quedó unido cuando una hermana del arcediano Torres, Bernarda, se casó con Juan (?) de Navarijo. María de Navarijo, cuñada de Bernarda y, por tanto, pariente política de Torres, se casó con Juan Rodríguez Sánchez. De este enlace nacieron Francisco Rodríguez Navarijo y dos hermanas más. Ignoro en qué momento de la vida de Francisco se dio la estrecha comunicación con su tío político Torres y Vergara, pero ya para los primeros años del siglo XVIII estaba viviendo en su casa. Es muy probable que incluso Francisco haya sido alumno de su tío en Prima de Leyes. El caso es que siguió de cerca sus pasos. 


\section{Una actividad pasajera: la abogacía práctica}

Torres Vergara, igual que haría después su sobrino, estudió derecho canónico y civil en la Real Universidad de México en la década de 1680, saberes muy cotizados en el mundo occidental de la época por ser la puerta para diferentes cargos de gobierno y administración. En Nueva España no era diferente, pues el contingente de jóvenes que estudiaban jurisprudencia en la universidad fue el más importante de todos ${ }^{15}$.

Cuando Torres se graduó de bachiller en cánones y en leyes, a la edad de 21 años, comenzó su carrera pública. De inmediato se tituló de abogado en 1681, hecho que le posibilitó ejercer la profesión. Ya desde entonces había una considerable competencia entre juristas y abogados en la ciudad de México, debido a su gran número ${ }^{16}$. En esas condiciones es entendible que Torres recibiera la protección de su propio padre, regidor de la ciudad por esos años ${ }^{17}$, para colocarse como abogado del ayuntamiento capitalino, su primer cargo de importancia.

Torres se desempeñó como abogado de la ciudad entre los años de 1683 y 1691 aproximadamente. Ignoro aún cómo fue su desempeño, pero a juzgar por su relación de méritos de 1698, es casi seguro que ya no logró nada importante en ese ámbito ${ }^{18}$. Sin mayores recursos ni recomendaciones en la "letradería" civil, las expectativas de Torres terminaron en esa comunidad y acabó por inclinarse por la carrera eclesiástica hacia 1686-1687, cuando obtuvo las órdenes sacras ${ }^{19}$. Como otros juristas, antes y después de él, Torres prefirió forjarse un futuro entre la jerarquía católica del arzobispado ${ }^{20}$.

15 Aguirre, "Los monarcas borbones y la burocracia en Nueva España”, El mérito y la estrategia.

16 Francisco de Icaza Dufour, La abogacía en el reino de Nueva España 1521-1821 (México: Miguel Ángel Porrúa, 1998), 77-79.

17 María Luisa J. Pazos Pazos, El ayuntamiento de la ciudad de México en el siglo XVII: continuidad institucional y cambio social (Sevilla: Diputación de Sevilla, 1999), 377. Juan de Torres se hizo a una regiduría del ayuntamiento de México hacia 1683, ofreciendo pagarla en abonos. Por esa época, según la misma autora, los cargos del ayuntamiento habían perdido interés para la oligarquía criolla debido a la fuerte intromisión del poder virreinal y monárquico en la vida interna de la ciudad. Por ello, la mayoría de las regidurías salían a la venta en almoneda pública y costaba trabajo venderlas. Algunos mercaderes medianos, como Juan de Torres, llegaron a interesarse, más como posible escalón que con un verdadero interés por la ciudad. Juan de Torres posiblemente se trasladó a México como encomendero mercantil. Puesto que por los años que estuvo en el ayuntamiento hubo pocos regidores, no es difícil pensar que tuvo facilidad relativa para proponer a su hijo, joven abogado aún, como uno de los tres procuradores de número que le estaba permitido tener al gobierno de la ciudad.

18 Su padre no pudo pagar finalmente la regiduría por lo que acabó dejando el cabildo y con ello la posibilidad para conseguir algún cargo civil mejor para el hijo.

19 “Provisión de Clementinas de 1786”, AGN, Universidad, 94, y "Provisión de Instituta de 1687”, AGN, Universidad, 101.

20 He abordado el estudio de las expectativas de los juristas en dos trabajos previos: "El perfil de una élite académica en la Nueva España del siglo XVIII: los licenciados y doctores canonistas” y “¿Abogados o clérigos? Una disyuntiva de los juristas en la Nueva España del siglo XVIII”, en Universitarios en Nueva España, coord. Armando Pavón Romero (México: Centro de Estudios Sobre la Universidad; UNAM, 2003), 51-84 y 85-150, respectivamente. 


\section{La integración de Torres Vergara a espacios clericales: la corporación universitaria y la curia arzobispal}

Para la clerecía del arzobispado de México la universidad fue un espacio propicio para generar relaciones y oportunidades de ascenso. Tanto por las familias de origen como por la profesión y las ligas históricas con otras corporaciones y los poderes virreinales, los miembros de la universidad configuraban un conjunto heterogéneo que compartía un espacio, académico en principio, definido por ciertos privilegios, que beneficiaba a todos en menor o mayor medida. Los grupos y comunidades presentes en la universidad no eran iguales, ni en cantidad ni en influencia ${ }^{21}$. En el claustro universitario, máximo órgano de gobierno conformado por doctores, predominaba el alto clero del arzobispado y sus clientelas.

En ese contexto debemos entender la decisión de Torres de obtener el grado de doctor en 1683, privilegio que solo una minoría de letrados alcanzó a lo largo de la época colonial, en general buscado por aquellos que siguieron una carrera eclesiástica ${ }^{22}$. Por ello era importante escoger a un buen padrino de grado que a futuro pudiera convertirse en un protector o, mucho mejor, que introdujera al ahijado a un grupo o subred clerical. Tal parece haber sido la intención de Torres al conseguir como padrino y mecenas de grado al clérigo y doctor Juan de Narváez, rector de la universidad, quien por entonces se hallaba en franca carrera para ingresar al cabildo catedralicio de México $^{23}$. La relación maestro-alumno se transformaba en el lazo prebendado-clérigo fuera de la universidad. Torres no se equivocó, pues hacia 1686 su padrino obtuvo finalmente una prebenda en el cabildo mexicano ${ }^{24}$ y él una posibilidad de recomendación para futuros ascensos. Es sabido que los miembros de los cabildos acostumbraban ayudar a toda suerte de ahijados a colocarse en curatos u obtener otros cargos ${ }^{25}$.

En tanto las relaciones con los capitulares de la catedral se consolidaban, Torres inició la línea de las cátedras universitarias, sólida plataforma de ascensos. Para fines del siglo XVII la cátedra universitaria se había convertido, para los clérigos, en una especie de prebenda eclesiástica, dada la gran influencia del alto clero en su provisión ${ }^{26}$.

21 Leticia Pérez Puente, Universidad de doctores (México: Centro de Estudios sobre la Universidad; UNAM, 2000); Enrique González, "Legislación y poderes en la universidad colonial de México (1551-1668)" (tesis doctoral, Universidad de Valencia, 1990).

22 Aguirre, “Los espacios en las instituciones eclesiásticas”, El mérito y la estrategia.

23 AGN, Universidad, 263, fols. 453-468. Ser padrino de un nuevo doctor daba buena fama, aspecto fundamental en la sociedad de la época.

24 Enrique González, "Mecenazgo y literatura. Los destinos dispares de Juan de Narváez y Siguenza y Góngora”, en Carrera, linaje y patronazgo. Clérigos y juristas en Nueva España, Chile y Perú (siglos $X V I-X V I I I)$, coord. Rodolfo Aguirre (México: Centro de Estudios sobre la Universidad; Plaza y Valdés, 2004).

25 “Cartas del arzobispo-virrey Juan Antonio de Vizarrón, sobre la provisión de curatos de Puebla en ahijados del cabildo catedralicio” (1738-1742), AGI, México, 806.

26 Rodolfo Aguirre Salvador, Por el camino de las letras. El ascenso profesional de los catedráticos juristas de la Nueva España. Siglo XVIII (México: Centro de Estudios Ssbre la Universidad; UNAM, 1998). 
Torres inició las oposiciones para las cátedras de las facultades de Leyes y Cánones hacia $1683^{27}$, estrategia común de los clérigos juristas de la capital. A sus lecciones de oposición comenzaron a asistir personalidades del alto clero integrados a la universidad, que sin duda le redituaron reconocimiento público. Hacia 1688, a los 27 años de edad, Torres obtuvo su primera cátedra: la sustitución de Vísperas de Leyes ${ }^{28}$ que era la de menor jerarquía en esa facultad. No obstante, lo verdaderamente importante fue que su integración al cuerpo de catedráticos universitarios, dada la alta incidencia cátedra-prebenda, le indicaba su aceptación en el grupo del alto clero, no solamente para ganar cátedras sino para futuras prebendas o cargos eclesiásticos ${ }^{29}$.

El hecho de que Torres contase con el voto del arzobispo, como juez de cátedras en la universidad, le abrió las puertas de la curia arzobispal: en 1691, a los 30 años de edad, fue nombrado provisor de indios y juez para asuntos de Guadalajara por el mismo prelado. $\mathrm{Al}$ año siguiente fue ascendido a uno de los más altos cargos del arzobispado: juez de testamentos, capellanías y obras pías, el cual ya no dejó sino hasta su deceso, 36 años más tarde ${ }^{30}$. El acceder a tales cargos constituía una verdadera oportunidad de integrarse como favorito del arzobispo. La conformación humana de la curia, tanto en períodos de sede plena como de sede vacante, era dinámica y podía implicar todo un proceso de negociación, o bien, de sustitución entre dos o más grupos, encabezados generalmente por el arzobispo o los capitulares de catedral, quienes se erigían como protectores y patrones de un amplio grupo de clérigos, tanto peninsulares como nativos ${ }^{31}$.

En una década, entre 1683 y 1692, Torres Vergara se había colocado en la antesala del cabildo eclesiástico, no sin una fuerte competencia en un medio en donde práctica-

27 Torres y Vergara inició su ascenso en la universidad en 1684 como sustituto del catedrático de Vísperas de Leyes en los meses de junio a septiembre. Las constituciones de la universidad dejaban a los catedráticos titulares nombrar sustitutos en los últimos meses del ciclo escolar. Ello permitía a los jóvenes graduados comenzar a ejercitarse en la docencia. Por ese mismo año, Torres inició sus oposiciones para cátedras, y entre 1684 y 1687 concursó en cinco ocasiones.

28 “Provisión de la cátedra de Vísperas de Leyes en sustitución de 1688”, AGN, Universidad, 101. En noviembre de 1688, Torres se presentó a concursar debido a la jubilación del doctor Francisco de Aguilar, quien le había dado en 1682 el grado de bachiller en leyes. Su fiador fue su propio padre, siendo rector Rodrigo García Flores, a la sazón cura de la capital y cercano al cabildo, personaje que se integraría al grupo familiar de Torres y que incluso llegaría a ser deán. Los jueces de la votación fueron el arzobispo Aguiar y Seixas, los oidores Juan de Arechaga y Francisco Marmolejo, el rector Francisco de Aguilar, el maestrescuela Juan Ignacio de Hoyos Santillana y el decano de la facultad de Leyes, el doctor José Osorio Espinosa. La votación: cuatro votos para Torres y dos para Amurrio. Ibídem.

29 En el arzobispado de México los catedráticos de Teología y Cánones conformaban un subgrupo clerical de mucho peso, no solo por la importancia que la cátedra tenía en la carrera eclesiástica sino por sus estrechas ligas con el alto clero del arzobispado y aun con la corte ibérica.

30 AGN, Universidad, 101. Relación de méritos del doctor José de Torres y Vergara. Además del puesto honorífico de subpromotor para la beatificación de Gregorio López, el cargo de juez de testamentos era, junto con el de provisor, el más importante de la curia debido al manejo de los cuantiosos capitales de origen pío. Todo indica que Torres se desempeñó eficazmente y se ganó toda la confianza del arzobispo Aguiar y Seijas. Uno de sus colegas, un prebendado, calificó su talento de superlativo.

31 He abordado tal problemática en: "Los límites de la carrera eclesiástica en el arzobispado de México. 1730-1748”, Carrera, linaje y patronazgo. 
mente todos los clérigos con altos grados académicos se sentían con derecho a los mismos nombramientos. Una feliz combinación de méritos personales y de la protección subsiguiente de su padre, su padrino de grado y el arzobispo le dieron resultado: se había convertido en un candidato idóneo para acceder a las codiciadas prebendas de catedral.

La llegada de Torres Vergara al juzgado de testamentos le dio una amplia presencia y reconocimiento en los círculos clericales y el crédito eclesiástico del arzobispado ${ }^{32}$, lo que se tradujo a su vez en un ascenso regular en las cátedras universitarias y la consecución de uno de los principales curatos de la arquidiócesis, por lo menos hasta antes de que falleciera su gran protector, el arzobispo Aguiar y Seijas ${ }^{33}$. Así, concursó y obtuvo sin dificultad en 1698 un curato de catedral. Sin embargo, para fines de ese año, ya sin la protección del arzobispo y con un enemigo de peso en el cabildo en sede vacante, que incluso había provocado su salida del juzgado de testamentos, Torres se presentó en la universidad a concursar por la propiedad de Prima de Leyes, perdiendo por un voto de diferencia ${ }^{34}$. No cabía duda de que Torres hasta ese momento había dependido más de la protección del prelado que de la del cabildo, con la diferencia de que aquel se iba y este último permanecía. Quizá por ello cambió su estrategia en el futuro.

Con todo, nuestro personaje no se dejó vencer por el grupo opositor del cabildo en sede vacante y recusó a su líder en una carta que envió al presidente de la junta de votación, poniendo al descubierto los entretelones en los que se movía el alto clero del arzobispado. En síntesis, Torres declaró que tres de los cinco votos posibles ya esta-

32 El juzgado de testamentos se había convertido en una fuente de créditos muy importante para miembros de varios sectores de la población. Véase a Gisela von Wobeser, El crédito eclesiástico en la Nueva España. Siglo XVIII (México: Instituto de Investigaciones Históricas; UNAM, 1994), y los trabajos recopilados por Pilar Martínez López-Cano, Gisela von Wobeser y Juan Guillermo Muñoz, Cofradías, capellanías y obras pías en la América colonial (México: Instituto de Investigaciones Históricas; UNAM, 1998).

33 En 1693, ya siendo juez de testamentos, Torres obtuvo su segunda cátedra, la de Instituta. En 1696 renunció a ella por haber ganado la propiedad de Vísperas de Cánones. En el mismo año vuelve a concursar por una canonjía doctoral de la catedral metropolitana. Hasta ese momento, había conseguido sus mayores logros en la universidad, pues cimentaba su carrera como catedrático con miras a obtener una de las primeras cátedras, hacer antigüedad y jubilarse. Según las constituciones universitarias, un catedrático que aspirara a jubilarse debía sumar un mínimo de 20 años de antigüedad. En el caso de los juristas, se les tomaba en cuenta los años de lectura tanto en la facultad de Leyes como en la de Cánones. Aguirre, Por el camino, 94-101.

34 “Provisión de Prima de Leyes” (1698), AGN, Universidad, 101. Durante el proceso de provisión de dicha cátedra, el doctor presentó por primera vez una relación de méritos impresa en la universidad, en la que informaba de su preparación académica, los cargos obtenidos hasta ese año y su desempeño como opositor y catedrático. Aunque en la votación del jurado no resultó victorioso, protestó por la irregularidad de los votos del designado, de tal manera que el pleito llegó hasta el Consejo de Indias. Torres pretendía que se anularan los votos del ganador y que la cátedra se le otorgara a él. El proceso duró tres años y al final nuestro doctor obtuvo la codiciada cátedra de Prima de Leyes en 1701, a los 40 años de edad. En 1711 se jubiló, aunque siguió leyendo hasta 1718, fecha en que abandonó definitivamente la cátedra, luego de 28 años de docencia y 57 de edad. 
ban decididos de antemano a favor del doctor José Cabrera Ponce de León, nuevo juez de testamentos, por maniobra del provisor Manuel Escalante y Mendoza, enemigo declarado del primero. Torres expresó que el provisor lo odiaba, inmerecidamente, por dos asuntos: por haberle negado su voto en la elección de vicecancelario de la universidad y por una decisión en el juzgado de testamentos que le había afectado. Al rector de la universidad, también juez de votación, lo definió como una auténtica "hechura” del provisor. Finalmente, también recusaba al oidor, Juan de Escalante, hermano del mismo provisor.

A pesar de tales acusaciones, la votación se llevó a cabo y salió electo el favorito del provisor, precisamente con tres votos y solo dos para Torres. Estos acontecimientos prueban que la provisión de cátedras, curatos y prebendas estaba sujeta a relaciones de fuerza entre grupos y que el talento personal era secundario. Torres no se rindió y apeló la votación ante el mismo Consejo de Indias, por lo que el virrey suspendió el proceso de provisión, ordenó nombrar un lector interino y pidió esperar la resolución de Madrid. Algunos meses después murió el aspirante electo por Manuel de Escalante, lo que sin duda facilitó a Torres su designación final como catedrático titular en 1701 y a cuya posesión asistió personalmente el nuevo arzobispo Juan de Ortega y Montañés, algo inusual ${ }^{35}$.

\section{El acceso de Torres Vergara al cabildo catedralicio de México}

Tanto en el cabildo catedralicio como alrededor de él se había constituido un tejido de relaciones e influencias capaz de generar grupos poderosos, no solamente por la alta investidura y prestigio de que gozaban lo prebendados sino también por la gran influencia y poder de decisión que tenían en la distribución de curatos, cátedras y canonjías, por no mencionar sus grandes atribuciones en sede vacante ${ }^{36}$. Alrededor del cabildo se formaban grupos clientelares y de ahijados que confiaban en formar parte del mismo algún día, como fue el caso de Torres Vergara ${ }^{37}$.

Con el respaldo de la máxima cátedra de Leyes y del cargo de juez de testamentos, Torres se propuso ingresar a dos de los espacios importantes del arzobispado durante el gobierno de Aguiar y Seijas: los curatos de la capital y las canonjías de oficio. Para estas, en especial, se hizo presente en las oposiciones de México, de Puebla y de Valladolid, aunque en las dos últimas fuera únicamente para sumar méritos o, como se usaba en la época, para "meritarse", pues era claro que desarrollaría toda su carrera en la capital. Lo interesante aquí es advertir que en los concursos de México se

\footnotetext{
35 “Provisión de la cátedra de Prima de Leyes en propiedad de 1698”, AGN, Universidad, 101.

36 Gabriela Oropeza, "Las actas del cabildo de la catedral de México, 1637-1644” (tesis de licenciatura en Historia, UNAM, 2004).

37 “Cartas del arzobispo Juan Antonio de Vizarrón y Eguiarreta, 1738-1742”, AGI, México, 806; Óscar Mazín, El cabildo catedral de Valladolid de Michoacán (México: El Colegio de Michoacán, 2000).
} 
encontraría con autoridades que ya le habían dado los cargos anteriores: el arzobispo, el maestrescuela y algunos canónigos.

A pesar de que Torres no consiguió pronto la canonjía de oficio y de sus tropiezos durante la sede vacante, no desfalleció, pues una parte del cabildo lo apoyaba. Además, al iniciar el nuevo siglo, su antiguo enemigo Escalante partió de la capital y el nuevo arzobispo Ortega y Montañés se apoyó en el grupo al que pertenecía Torres para hacerle contrapeso al poder de los capitulares que dirigieron el arzobispado en la sede vacante. Mejor aún para Torres, el arzobispo lo restituyó en el juzgado de testamentos y su nombre comenzó a figurar en las consultas del Consejo de Indias ${ }^{38}$, prueba del reconocimiento y protección del nuevo arzobispo. Luego de casi dos décadas de iniciada la carrera eclesiástica, nuestro personaje finalmente obtuvo una media ración en $1704^{39}$. A partir de ese momento su ascenso por las prebendas y dignidades fue sistemático: de medio racionero a racionero, luego a canónigo, tesorero, maestrescuela y finalmente a arcediano, poco antes de morir en $1727^{40}$.

Durante ese período de tiempo, 1704-1727, Torres Vergara se convirtió en una de las cabezas del arzobispado pues no solamente gobernó el juzgado de testamentos, aún en una sede vacante. Así, además de tener el control de las capellanías y los capellanes, encabezó la defensa del claustro de doctores de la universidad ante un largo pleito con el Colegio Mayor de Todos Santos. Torres también se desempeñó como examinador de los aspirantes a ordenarse de sacerdotes y, cuando accedió a la maestrescolía, pudo dar los grados mayores de la universidad a los futuros dirigentes del arzobispado. Por supuesto, tal concentración de poder no fue el resultado de acciones individuales.

\section{Torres Vergara y los grupos clericales del arzobispado}

El encumbramiento de Torres no podría entenderse sin explicar su pertenencia a grupos clericales concretos que a lo largo de su carrera influyeron de diferente forma. Torres constituyó un primer núcleo familiar-clerical, el más cercano afectivamente hablando, al que pertenecían no solo consanguíneos sino también amigos. Estableció en su propia casa un grupo de clérigos que figuraron, o aspiraron a figurar, en el horizonte más alto del arzobispado: el doctor Rodrigo García Flores de Valdés, quien

38 Sobre la consultas para prebendas eclesiásticas en el Consejo de Indias puede verse el trabajo de Lucrecia Enríquez Agrazar, "Vacancias eclesiásticas y ascenso social en Chile en el siglo XVIII”, en Memoria del 51 Congreso Internacional de Americanistas (Santiago: Universidad de Chile, 2003). CD-ROM.

39 AGI, Indiferente, 2863, lib. 4. El nombramiento real tiene fecha de 13 de febrero de 1704.

40 AGI Indiferente, 2863, lib. 4. Otros cargos menores, más de tipo honorífico, fueron el de examinador sinodal y el de consultor de la Inquisición. Además fue designado capellán de las carmelitas descalzas del convento de San José y llego a ser incluso abad de la congregación de sacerdotes de San Pedro, cargo honorífico de la confraternidad sacerdotal más importante del arzobispado. 
llegó a ser deán del cabildo ${ }^{41}$; el doctor Francisco Rodríguez Navarijo, su sobrino político ${ }^{42}$, prebendado, catedrático de Vísperas de Leyes, que llegaría a ser maestrescuela; así como los doctores Esteban de Salas y, otro sobrino, José Antonio Navarijo y Torres, ambos presbíteros y abogados. Este grupo permaneció por lo menos hasta la desaparición de Torres y del deán García Flores y estuvo cohesionado básicamente por relaciones afectivas, de las que dependieron recomendaciones y apoyos desde otros espacios.

Este núcleo familiar se articuló a otros grupos de origen corporativo y político que en las tres primeras décadas del siglo XVIII tuvieron una presencia central en la vida clerical de la ciudad de México. La coyuntura fue un conflicto entre la Real Universidad y el Colegio Mayor de Todos Santos ${ }^{43}$, el cual rebasó los ámbitos de las dos corporaciones y dejó al descubierto una pugna entre el alto clero y los oidores de la real audiencia. La universidad fue, en realidad, el campo de batalla de ambos grupos.

Durante el conflicto, los catedráticos juristas de la universidad, designados por las constituciones como encargados de su defensa, jugaron un doble papel: como abogados de la corporación y como clérigos al servicio de los intereses de la jerarquía eclesiástica ${ }^{44}$. Primero Torres y después Rodríguez se vieron inmersos en el conflicto en el cual, al proteger los privilegios de la universidad, protegieron en realidad los del cabildo catedralicio y su clientela: los doctores clérigos que buscaban beneficios y prebendas eclesiásticas ${ }^{45}$.

41 Cuando Flores ascendió al deanato de México, quizá algo inusual para un criollo, hacia 1716, quiso demostrar esa honra máxima pidiendo que le llevaran al mismo coro de catedral la urna para votar un examen de licenciatura, lo cual fue evidentemente un exceso, al cual se opuso el maestrescuela Madriz y Bustamante, aunque apoyado por Torres y el rector Pedro Fernández de los Ríos. AGN, Universidad, 71, exp. 1 (1716).

42 AGN, Bienes Nacionales, leg. 813, exp. 6, sobre el cumplimiento del testamento del doctor José Torres Vergara.

43 El pleito se generó por la intención de los miembros del Colegio Mayor de Todos Santos de gozar de prerrogativas dentro de la universidad.

44 "Autos hechos sobre la pretensión que hace en ésta real universidad el colegio mayor de Santos de esta corte sobre el que se le exonere y quite la calidad de ser recíproco el recibir y dar propinas para sus grados mayores, según lo determinado en claustro y demás que expresa” (1705), AGN, Universidad, 70, exp. 1, 71. Hacia 1706, los catedráticos juristas encargados de defender a la universidad ante el colegio fueron: Diego Franco, Carlos Bermúdez, José de León, Juan Pérez Rivero y Agustín Franco. Hacia 1714, Torres y Rodríguez actuaron directamente. Los juristas clérigos llegaron a ser altos dignatarios de la iglesia novohispana: Torres Vergara, arcediano; Nicolás Carlos Gómez de Cervantes, obispo de Guadalajara; Bermúdez de Castro, arzobispo de Manila: Juan José de la Mota, cura de Santa Catarina, y Francisco Rodríguez Navarijo, maestrescuela.

45 Actualmente trabajo en el proyecto de investigación "Corporaciones y poder en Nueva España. La Real Universidad de México y el Colegio Mayor de Todos Santos” en el cual profundizaré precisamente en la interrelación entre las corporaciones y sus miembros como una característica del orden político prevaleciente en la capital novohispana. 
Pero Torres no solo actuó desde la universidad, como doctor de su claustro y su abogado, sino también desde el juzgado que dirigía, al promover un préstamo de sus arcas a la primera para hacer frente a los gastos del pleito en Madrid ${ }^{46}$. El conflicto con el colegio le dio la oportunidad de convertirse en una de las “cabezas” del cabildo, de integrar a jóvenes clérigos, como sus sobrinos, a la órbita clientelar del alto clero y de preparar su propio ascenso a las dignidades eclesiásticas. Un clérigo preferido fue, obviamente, el sobrino Francisco Rodríguez Navarijo, joven doctor que comenzó a hacerse presente en los medios clericales, haciendo méritos pero sobre todo buenas relaciones al amparo del tío.

El reconocimiento que adquirieron los abogados de la universidad fue concretado con prebendas, canonjías y dignidades. Torres Vergara, en pleno apogeo del conflicto con el Colegio Mayor, recibió un amplio apoyo para ascender a la vicecancelaría de la universidad y, por tanto, a la maestrescolía ${ }^{47}$. El proceso que le antecedió es una magnífica oportunidad para estudiar las redes de apoyo a los diferentes candidatos.

Al claustro universitario del 15 de junio de 1718, convocado por el rector para elegir la terna, asistieron 92 doctores de todas las facultades, número inusual, reflejando la importancia que tenía el evento ${ }^{48}$. Doctores que no acostumbraban a ir a los claustros se hacían presentes para apoyar con su voto, secreto en principio, a alguno de los propuestos. En esta ocasión el rector propuso conformar la terna de entre los doce doctores clérigos con más méritos: seis prebendados y seis curas de la capital. Entre los asistentes se encontraban, por supuesto, los familiares, amigos y clientes de Torres ${ }^{49}$.

El resultado de la votación fue contrastante, pues mientras para Torres hubo casi unanimidad para ir en primer lugar de la terna, para el segundo y el tercero los votos se dividieron completamente ${ }^{50}$. La composición de la terna, un dignatario y dos ca-

46 AGN, Universidad, 71, fs. 57-58v, hay un traslado de una escritura original del juzgado de testamentos en donde Torres libera a la universidad del depósito irregular por 6.000 pesos de principal de dos capellanías. Se declara que en 1706 el arzobispo y el juez autorizaron la entrega de esa cantidad a la universidad, quien pagó puntualmente los réditos a los capellanes correspondientes.

47 Puesto que el maestrescuela tenía como cargo anexo el de cancelario de la universidad, al morir el rey se concedió el privilegio al claustro universitario de elegir a una terna de entre los doctores clérigos más antiguos y beneméritos para que el virrey eligiera a un vicecancelario, en tanto el rey nombraba al nuevo maestrescuela. Era costumbre de la universidad pedir al monarca que al vicecancelario electo lo nombrará maestrescuela.

48 “Claustro de 15 de julio de 1718”, AGN, Universidad, 20. Los propuestos fueron: a) prebendados: Lucas Verdiguer, José Torres, Nicolás Contreras, Nicolás Carlos Gómez de Cervantes, Carlos Bermúdez y Juan Ignacio Castorena; b) curas: Pedro del Castillo, Miguel de Roxas, Juan José de la Mota, Pedro Ramírez, Nicolás Sánchez y Juan de Aldabe.

49 El arcediano, y padrino de Torres, Antonio de Villaseñor Monrroy, y sus sobrinos Francisco e Ignacio Rodríguez Navarijo. No asistió Rodrigo García Flores, para entonces ya deán del cabildo.

50 Votación para primer lugar: 88 para Torres, 1 para Verdiguer, 3 para Nicolás Carlos Gómez de Cervantes, 1 para Bermúdez y 1 para Castorena. Para segundo: 51 para Verdiguer, canónigo magistral, 37 para Castorena, 4 para Nicolás Gómez Cervantes y 2 para Bermúdez. Para tercero: 43 para Castorena, 27 para Bermúdez, 5 para Contreras, 17 para Cervantes, 1 para Castillo y 1 para Ramírez. 
nónigos del cabildo, reflejaba el dominio, otra vez, del alto clero del arzobispado en el claustro de la universidad. El virrey no tuvo ningún reparo en escoger a Torres Vergara, y un año después este tomaba posesión de la cancelaría, al ser nombrado por el rey como nuevo maestrescuela. En esta ocasión solo asistieron 58 doctores, entre ellos su hermano y dos de sus sobrinos, que reflejan su proximidad a la subred clerical a la que pertenecía, conformada por parte de la jerarquía media y baja del cabildo, curas de la capital, catedráticos de la universidad y jóvenes doctores ${ }^{51}$.

El cargo de maestrescuela le otorgó a Torres, además del privilegio de dar los grados mayores en la universidad, un asiento en la junta de votación de cátedras, establecida en 1676 por el rey. El cargo otorgaba tanto poder, presencia y prestigio en el medio intelectual que nuestro personaje se negó incluso a ascender a la chantría en el cabildo, con tal de no alejarse de tal espacio. Poco antes de morir, en 1727, tuvo que aceptar el arcedianato del cabildo, pues negarse por segunda vez a una designación real era inconcebible ${ }^{52}$.

\section{Integración de Rodríguez Navarijo al ámbito clerical del tío}

La relación familiar de Rodríguez con su tío fue muy estrecha y con el tiempo se convirtió en relación política, para provecho de ambos. La integración de Rodríguez Navarijo a los círculos clericales antes vistos: universidad, catedráticos, curatos y, finalmente, el cabildo, no fue en absoluto circunstancial. Es factible comprobar que desde el inicio hasta la plena consolidación de su carrera contó con la protección de su tío, de los amigos de este y, por último, del grupo clerical dirigente del cabildo catedralicio.

Por los años en que Torres Vergara alcanzó la máxima cátedra en la universidad, recuperó el juzgado de testamentos e ingresó al cabildo (1701-1704), su sobrino Rodríguez Navarijo iniciaba su carrera eclesiástica y es posible que ya hubiera cambiado su residencia a la casa de su tío político. Aunque Rodríguez se tituló de abogado, tal profesión fue solo una forma pasajera de subsistir en tanto se "meritaba" mejor para iniciar la carrera hacia el cabildo, tal y como lo había hecho su tío 20 años atrás ${ }^{53}$.

51 “Claustro de 19 de julio de 1719”, AGN, Universidad, 20.

52 José Mariano Beristain de Souza, Biblioteca Hispanoamericana Septentrional, vol. 2 (México: UNAM, 1980). En esta obra se anotan dos textos que escribió Torres en 1722 y 1725 respectivamente: Respuesta jurídica al señor deán doctor don Rodrigo García Flores sobre la costumbre de no ganar los prebendados enfermos el derecho de acreces, ni manuales de aniversarios y sobre la inteligencia de los estatutos de la iglesia de México en esta materia. Impreso en México por Rodríguez Lupercio, 1722, 4, y Disertación canónico-moral sobre que la costumbre de la metropolitana de México de que los prebendados enfermos no ganen la porción vacante de derecho de acrecer, es racional, preescrita, laudable, santa y favorable al culto. México, 1725.

53 Un sector de abogados en Nueva España seguía este patrón; es decir, ejercer por algunos años mientras preparaban su incursión en la administración y tribunales eclesiásticos. Al respecto, he tratado el tema en “¿Abogados o clérigos?”, 120-136. 
En tanto, comenzó a presentarse en las oposiciones a cátedras para hacer méritos ${ }^{54}$. Cuando alcanzó el grado de doctor, en 1706, y el presbiterado, estuvo en condiciones reales de competir por las cátedras, los curatos y las canonjías ${ }^{55}$. No sería raro comprobar que Antonio de Villaseñor Monrroy, canónigo, aceptara ser su padrino de doctorado gracias a la petición de Torres. Igualmente, el tío ya tenía una relación estrecha con Rodrigo García Flores de Valdés, canónigo del cabildo. En otras palabras, Torres fue quien integró al sobrino a la órbita del cabildo catedralicio y del mismo arzobispo.

Una prueba clara de la protección que recibió Rodríguez la encontramos en el proceso de provisión de la cátedra de Prima de Cánones de la universidad en 1706, siendo apenas su segundo intento. La lección para concursar la elaboró en casa de Torres Vergara, lo que comprueba que ya desde entonces Rodríguez vivía ahí. El apoyo mayoritario de la junta de votación al sobrino de Torres demuestra que valía más de quién se fuera familiar o recomendado que los méritos personales ${ }^{56}$. Un colegial de Todos Santos, amigo del competidor más fuerte que tuvo Rodríguez en ese concurso, señalaría después cuál había sido el mayor mérito de este:

[...] por noviembre de 706 se votó la cátedra de Prima de Cánones en sustitución de la Universidad siendo, entre otros, opositor don José Venegas de Espinosa su colegial, sujeto de gran calidad, literatura y dignidad, muy meritado en oposiciones a cátedras y sustituto de la de Código, y el doctor don Francisco Navarijo muy moderno pero de mucho valimiento por sobrino del doctor José de Torres, doméstico, oficial visitador de capellanías del reverendo arzobispo, que tiene aquella poderosa mano que es notoria en el reino, con que violentó los votos a sufragar por el doctor Navarijo en quien la proveyó por mayor parte de votos ${ }^{57}$.

Esta declaración, más que probar lo extraordinario del caso, que no lo era en absoluto, pues muchos catedráticos se valían del mismo tipo de influencias para ganar, nos da elementos clave para entender la conformación política del alto clero del arzobispado, es decir, la articulación de grupos familiares, como el de Torres, con grupos corporativos, como el dominante del cabildo catedralicio, y con grupos afines al gobierno arzobispal, presentes en la provisión de las cátedras. En otras palabras: si el arzobispo

54 “Provisión de la cátedra de Clementinas de 1709”, AGN, Universidad, 95. Según la relación de méritos de Rodríguez Navarijo, hacia 1701 participó en un acto de estatuto, tuvo siete sustituciones de catedráticos titulares por algunos meses y tres oposiciones a cátedras.

55 AGN, Universidad, 264, fols. 154-170v.

56 “Provisión de la sustitución de Prima de Cánones”, (1706) AGN, Universidad, 95. En esta ocasión, el joven doctor Rodríguez consiguió siete de los ocho votos posibles de la junta de votación. El otro aspirante que consiguió el octavo, el bachiller José Leandro Venegas de Espinosa, colegial de Todos Santos, exigió poner guardas a ambos durante la elaboración de la lección, norma establecida en las constituciones, pero que no se acostumbraba. Este sería uno de varios enfrentamientos con el partido colegial.

57 “Expedientes sobre colegios de estudios en aquella audiencia, años de 1703 a 1753” (1708), AGI, México, 643. Carta de Nicolás de Oliván Rebolledo, rector del Colegio Mayor de Todos Santos, al rey. Resaltado del autor. 
Ortega Montañés ayudó a Rodríguez, no fue por él mismo, pues era muy raro que los prelados asistieran a las lecciones de los opositores, sino por ser sobrino de su juez de testamentos, quien era también miembro del cabildo catedralicio y catedrático de propiedad en la universidad.

El alcanzar tan rápido una primera cátedra fue señal para Rodríguez de que había iniciado bien su carrera eclesiástica. Hacía falta hacer otros méritos para justificar nuevos ascensos: una oposición a los curatos de la capital y otra a la canonjía doctoral, sin otra intención que hacerse presente. Acto seguido, gana Clementinas en 1709 con todos los votos, ya sin la presencia del arzobispo pero con el apoyo de los capitulares y clérigos dependientes ${ }^{58}$. Tanta era la confianza y la dependencia de Rodríguez con respecto a su tío y al grupo al que pertenecía que incluso rechazó un ascenso rápido a una canonjía de Oaxaca, pues era más importante no alejarse del arzobispado ${ }^{59}$.

En 1709 también aspiró por segunda vez a los curatos de México ${ }^{60}$. El convocante fue el deán del cabildo, el presidente del concurso: su padrino Villaseñor Monrroy. La ocasión no podía ser mejor al tener el cabildo en sede vacante todo el control de la provisión de curatos. Aunque Rodríguez no ganó ningún curato de la capital, los únicos que le interesaban en realidad, no se fue con las manos vacías: el cabildo lo designó como cura interino de la Santa Veracruz, posición estratégica justificante de un ascenso a corto plazo. El paso a la propiedad de la misma parroquia solo era cuestión de tiempo: hacia 1711, apenas en su segundo concurso de curatos, Rodríguez la obtuvo fácilmente con todos los votos del cabildo, logro que a un cura sin esas relaciones le podía llevar muchos años ${ }^{61}$. El mismo Torres Vergara le dio la colación y posesión del

58 “Provisión de la cátedra de Clementinas” (1709), AGN, Universidad, 95.

59 AGN, Universidad, 70, exp. 4 (1707): al final, testimonio de que casi nadie quiso aspirar a la canonjía doctoral de Oaxaca. El obispo pidió al virrey proveer. Este pidió al rector convocar a claustro para pedir a los doctores juristas que se presentaran al concurso. En dicho claustro de 29 de agosto de 1707, los pocos doctores y posibles candidatos se fueron excusando, entre ellos Mota, y Rodríguez Navarijo, quien, en especial, expresó: "no estar en aptitud para dicho fin atento a la residencia que pide su cátedra de sustitución de Prima de Cánones como las obligaciones de estar cuidando y asistiendo a la dilatada familia de tantas hermanas pobres como tiene y a que está atendiendo". Al final, nadie quiso ir a presentarse. El rector Manuel de la Peña pidió entonces al secretario buscar en sus casas a los juristas ausentes para que respondieran al decreto del virrey. La respuesta generalizada: ocupaciones, compromisos, enfermedades. El rector se limitó a informar de todo ello al virrey.

60 AGN, Bienes Nacionales, leg. 338, exp. 2.

61 “Gobierno sede vacante. Año de 1711. Autos hechos sobre la provisión de 9 curatos y beneficios vacantes en esta ciudad y arzobispado, de resulta de la provisión del año de 710”, AGN, Bienes Nacionales, 236, exp. 24. Los capitulares responsables eran: chantre: dr. Jerónimo López de Arbizu; maestrescuela: José Ibáñez de la Madriz; tesorero: Rodrigo García Flores de Valdés; canónigos: Villaseñor, Francisco Parcero y Ulloa, Domingo Antonio Bayón y Banduxo, Andrés Pérez Costela, Gonzáles de Valdeosera, Torres Vergara, Lucas Verdiguel; racioneros: Francisco Ximénez Paniagua, Manuel Bravo de Acuña; medio racioneros: Gabriel Basilio Nieto y José Riva de Astete. El secretario de gobierno: Castorena y Ursua. La votación la presidió Flores de Valdés, a falta de otras dignidades. Resultado: 15 votos para Rodríguez Navarijo. 
curato con las ceremonias acostumbradas, siendo testigos su primo José de Navarijo y su amigo Esteban de Salas. Lo familiar y lo clerical se confundían por completo.

De esa forma, durante los años de sede vacante, entre 1708-1712, Rodríguez Navarijo fue integrado a dos espacios con fuerte connotación "escalafonaria” o de ascenso: cátedras titulares de la universidad y curatos, cargos medios en la carrera eclesiástica.

En la época del arzobispo José Lanciego (1712-1727), tío y sobrino vieron avances muy importantes en sus carreras eclesiásticas, gracias, inicialmente, a la política conciliadora del prelado y a que reconoció al grupo dominante del cabildo ${ }^{62}$, del cual ellos formaban parte. Torres avanzó desde la canonjía hasta el arcedianato y fue conservado como juez de testamentos, señal inequívoca de que el arzobispo tendió a mantener el statu quo impuesto por el cabildo durante la sede vacante. La cercanía de Rodríguez con su tío, uno de los artífices de la defensa de la universidad contra el colegio, le ganó también reconocimiento y protección.

El arribo de los protectores de Rodríguez a las dignidades del cabildo (García Flores a chantre y luego a arcediano, Villaseñor Monrroy a tesorero y a chantre, y Torres Vergara a tesorero en 1716) influyó en su propio arribo a la catedral pues a partir de este ultimo año sobrevinieron consecutivamente los cargos importantes en su trayectoria: fue consultado por primera vez en el Consejo de Indias para una media ración de México ${ }^{63}$, en 1716 es recomendado por el cabildo catedralicio al rey ${ }^{64}$, en 1718 obtuvo la cátedra propietaria de Vísperas de Leyes, en 1722 obtiene una media ración, en 1727 la canonjía doctoral, en 1729 es nombrado por la universidad su vicecancelario y finalmente, en 1730, el rey lo nombra maestrescuela de México, último cargo que alcanzó en su carrera eclesiástica.

Los procesos que llevaron a Rodríguez a la canonjía doctoral y a la vicecancelaría universitaria ${ }^{65}$ evidencian la consolidación de sus lazos con las dignidades gobernan-

62 Rodolfo Aguirre Salvador, "El ascenso de los clérigos de Nueva España durante el gobierno del arzobispo José Lanciego y Eguilaz”, en Estudios de historia novohispana (México: Instituto de Investigaciones Históricas, UNAM), 22: 77-110.

63 Otros referentes fundamentales para ubicar mejor el inicio real del ascenso de Navarijo: el 06-08-1715 fue consultado en el Consejo de Indias en tercer lugar para una media ración del cabildo; igual sucedió el 19-02-1716 y el 02-12-1716, al lado siempre del segundo lugar, Pedro Ramírez del Castillo. Después de estos tres intentos, en una consulta de 1717 ni Ramírez ni Navarijo aparecen ya, y la siguiente consulta es de 1730 .

64 Nuevos indicios señalan que cuando Flores de Valdés llegó al deanato del cabildo su suerte cambió pues hacia 1716 el cabildo lo recomendaba en Madrid. Su tío ascendió en ese año también a la tesorería. Es decir, hacia 1716, Navarijo se encuentra en una situación muy favorable para intentar ya "saltar" al cabildo. Sus protectores, el deán, el maestrescuela y quizá su padrino de grado, se hallaban ya en dignidades, bien ubicados, y esto también lo favorece. AGI, Indiferente, 2863, libro 4.

65 Este cargo era, junto con el de rector, el más honorífico de la universidad pues daba derecho a su poseedor de otorgar los grados mayores de licenciado y doctor, como delegado papal. 
tes del cabildo y con el grupo clerical dominante en el claustro universitario. Respecto al primero, la votación fue muy dividida pues Rodríguez ganó solo por un voto de diferencia. Es muy posible que el voto lo diera su propio tío, dejando en la orilla a Juan José de la Mota, cura y catedrático con más antigüedad y méritos personales, y al más joven, Ignacio de Mesa, ambos funcionarios de la curia del arzobispo, en contraste con Navarijo, quien no desempeñó ningún cargo ahí66

El considerar a Rodríguez como favorito del cabildo y no del arzobispo se explica así. Meses atrás, el prelado había tenido un pleito con el cabildo por haber intentado sentar a su provisor en el coro ${ }^{67}$. La participación de Rodríguez fue la de hacer el escrito en derecho en el que el cabildo rechazaba dar un lugar en el coro a alguien que no perteneciera al cabildo, aunque fuera el provisor del arzobispo ${ }^{68}$. Es muy probable que el encargo haya sido del deán y protector suyo, Rodrigo García Flores de Valdés. Tal acción a favor del cabildo demostró públicamente a quién se debía más Rodríguez Navarijo y así fue premiado con los votos suficientes para ganar la canonjía doctoral dos años después. El cura Juan José de la Mota, a pesar de sus buenas relaciones con los clérigos de la capital, carecía de relaciones comparables con el cabildo, pues en realidad estaba más allegado al arzobispo.

Después de la gestión del arzobispo Lanciego, durante la sede vacante (1727-1730), ya sin la presencia del deán Rodrigo García y del arcediano Torres, Rodríguez Navarijo siguió contando con el apoyo del nuevo deán, y antiguo padrino, Antonio de Villaseñor, a tal grado que fue designado como nuevo provisor vicario general, quedando su

66 “Provisión de la canonjía doctoral de 1726-1727”, AGI, México, 802. El apoyo que recibió Navarijo es indudable hacia 1726, cuando, el 30 de marzo, el arzobispo Lanciego y el cabildo informaron de la terna para la canonjía doctoral, en la que hubo 20 aspirantes. El primer lugar fue para Navarijo, de 47 años de edad, quien obtuvo seis de los 11 votos, y de quien se destacaron, como principales méritos, ser medio racionero y aspirante a dos canonjías desde 1707. Su último mérito: ser juez hacedor en 1725. El segundo lugar fue para Juan José de la Mota, cura de catedral, de 52 años, abogado fiscal de la Inquisición desde 1722, aspirante a curatos y canonjías, predicador, nombrado por el arzobispo como examinador sinodal y juez privativo de las colecturías de misas de México, así como sustituto de diferentes funcionarios de la curia. El clero de la ciudad lo nombró por su diputado del colegio seminario. En el tercer lugar, otro protegido de Lanciego: Ignacio de Mesa, de 31 años, con cierta presencia en la universidad y abogado también, sustituto del relator apostólico del tribunal de Cruzada, aspirante a la canonjía de Valladolid. Su principal mérito: defensor del juzgado de testamentos, nombrado por Lanciego.

67 Aguirre, Por el camino, 121-122.

68 Lo refiere Beristain de Souza en el registro 2819: “Estampeta de San Antonio con el niño. Por el deán y cabildo de la Santa Iglesia Catedral Metropolitana de México, sobre que sus prebendados se mantengan en sus asientos en el coro, según la erección de ella, sin que deba incorporarse el provisor que no fuere prebendado, en fuerza de la ley real de Indias como ni en otro acto en que haya forma de cabildo. Motivo porque contradijo el lugar que violenta y atentadamente pretendió el provisor el día del Corpus 15 de junio del año pasado de 1724, estándose actualmente viendo el punto en el Real Acuerdo extraordinario. Formó esta defensa de mandato de dicho señor deán y cabildo el doctor don Francisco Rodríguez Navarijo, doctor en ambos derechos, abogado de esta real audiencia y de presos del Santo Oficio de la Inquisición de la Nueva España y catedrático de Vísperas de Leyes en su Real Universidad y prebendado de la misma Santa Iglesia Metropolitana” (1724). 
protector al frente del juzgado de testamentos ${ }^{69}$. De ahí que no fuera raro el que ganara la vicecancelaría de la universidad en $1729^{70}$. Tales logros en sede vacante significan que, con o sin la presencia del arzobispo, al tener Rodríguez la protección del deán podía continuar su marcha ascendente sin tropiezos. No obstante, el protector murió por el año de 1729 y las cosas cambiaron.

\section{Estancamiento de la carrera de Rodríguez Navarijo}

Con la llegada del nuevo arzobispo, Juan Antonio de Vizarrón, en 1730, las expectativas de Rodríguez y los suyos cambiaron, pues si su antecesor apoyó las carreras de los clérigos locales con resultados apreciables, dignidades y mitras, bajo el nuevo gobierno ya no fue así. Vizarrón se destacó por dar la preferencia a los clérigos de su familia y a algunos criollos de la nueva generación que le sirvieron bien, así como por cuestionar la capacidad intelectual de su clerecía ante Felipe V. De hecho, al final de su gobierno, el claustro de la universidad se quejó de que los ascensos para los catedráticos y doctores eclesiásticos habían escaseado mucho en las dos últimas décadas, precisamente cuando gobernó Vizarrón.

El mismo Rodríguez Navarijo vio estancada su carrera por el resto de su vida pues ni siquiera ascendió en el cabildo al arcedianato o deanato, como lo habían hecho sus protectores García Flores, Villaseñor Monrroy o Torres Vergara. Clérigos peninsulares y un nuevo grupo de doctores criollos jóvenes ocuparon las máximas dignidades. A esto hay que agregar que el nuevo prelado tuvo una visión muy diferente a su antecesor con respecto al ascenso del clero nativo.

La actitud del arzobispo fue restar poder gradualmente a los dirigentes del cabildo, sin llegar nunca a un enfrentamiento, y es casi seguro que para iniciar llegó a cierto entendimiento precisamente con Rodríguez Navarijo, conservándolo como provisor vicario general al igual que a sus subalternos, como el doctor José Flores Moreno, promotor fiscal. El respetar la posición de Rodríguez fue un gran acierto, dado el apoyo de que gozaba entre el alto clero, y lo mismo hizo con los intereses de sus allegados o protegidos. Paralelamente, buscó colocar a sus familiares gradualmente, sin provocar una oposición generalizada en el clero local, como estudié en otro trabajo $^{71}$. No sucedió lo mismo con el juez de testamentos, el canónigo Luis de Umpierres,

69 Juan Ignacio Castorena y Ursúa y Francisco Sahagún Arevalo, Gacetas de México (México: Secretaría de Educación Pública, 1949-1950), 1:72.

70 “Claustro de 16 de julio de 1729”, AGN, Universidad, 21. Como años atrás con su tío, en 1729 se reunieron el extraordinario número de 108 doctores para elegir la terna, aunque esta vez la votación fue más cerrada para el primer lugar. Rodríguez alcanzó 49 votos, frente a 36 y 18 del segundo y tercer nominado, respectivamente. Esta vez no hubo el consenso que sí alcanzó su tío. Con todo, cuando Rodríguez tomó posesión del nuevo cargo, asistieron justamente 49 doctores. El secretario de la universidad anotó en el registro lo inusual de ese número para tal tipo de eventos. No es difícil pensar que el mismo grupo que le dio su voto asistiera a festejarlo, y quizá a esperar futuros favores.

71 En un trabajo anterior sobre los familiares del arzobispo Juan Antonio Vizarrón Eguiarreta pude comprobar el accionar de su patronazgo para acomodarlos en altos cargos o prebendas eclesiásticas. Aunque Vizarrón Eguiarreta fue un padrino por demás visible y poderoso, no fue el único en el arzobispado. Es indudable que existieron otros "padrinos" que igualmente influyeron o pactaron ascensos o prebendas para sus familiares, clientes o subordinados. Véase, Aguirre, "Los límites de la carrera”. 
a quien lo sustituyó con un joven clérigo, miembro de su familia, José de Velasco Tejada.

Es claro que Vizarrón concilió con el grupo local más fuerte, buscando su desgaste con el tiempo. A Rodríguez particularmente no lo apoyó en Madrid para ascender al deanato. En 1738, el mismo Rodríguez renunció al cargo de provisor vicario general del arzobispado, precisamente cuando Vizarrón estaba más atareado al frente del virreinato. Las razones que tuvo para hacerlo siguen siendo una incógnita, pues no es fácil explicar por qué dejó tal espacio de poder y de influencia. Lo sustituyó el descendiente de una de las familias criollas más distinguidas de la época: el doctor Francisco Javier Gómez de Cervantes, clérigo sin mayores méritos que haber alcanzado una cátedra universitaria al amparo de su tío, el obispo de Guadalajara Nicolás Carlos Gómez de Cervantes ${ }^{72}$, y alejado del grupo Torres Vergara-Rodríguez Navarijo.

Paralelamente a lo que sucedía en el gobierno del arzobispado, la salida de Rodríguez del provisorato coincide con la pérdida de influencia del arzobispo en la provisión de cátedras de la universidad de México, en donde el primero era juez también y cuya influencia como maestrescuela era manifiesta. Es probable que estemos hablando de una ruptura entre el arzobispo Vizarrón y el grupo del maestrescuela, el cual habría sido sustituido en el control del cabildo por otro grupo, encabezado por el deán peninsular Ildefonso Moreno Castro, con mucho mejores relaciones con el prelado.

Un indicador de la pérdida de poder del maestrescuela aparece al revisar las trayectorias de su hermano Ignacio Rodríguez Navarijo y de sus sobrinos, que no pudieron hacer una carrera siquiera parecida al maestrescuela, a pesar de su indudable cercanía. Ignacio se doctoró en Teología en $1716^{73}$, justo cuando su hermano iniciaba los máximos ascensos en su carrera. Otro sobrino, José Antonio Navarijo Torres, se doctoró en cánones hacia $1718^{74}$. Por esa época el encumbrado era el tío José Torres Vergara, tesorero de catedral, y de él esperaban protección. Sin embargo, con su desaparición en 1727 y con el estancamiento de Francisco Rodríguez, los sobrinos vieron frustradas sus esperanzas de ascender en la jerarquía del arzobispado. Con pocos méritos y sin que el poder de Rodríguez fuera comparable al del tío Torres, tuvieron que conformarse con las rentas de importantes capellanías fundadas para ellos ${ }^{75}$.

Todavía en la sede vacante de 1747-1749, Francisco Rodríguez fue nombrado juez de testamentos, desplazando a José Velasco de Tejada, protegido del arzobispo anterior, hecho que indicaba la molestia del cabildo mexicano con respecto al gobierno arzobis-

\footnotetext{
72 Ganster, "La familia Gómez”, y Aguirre, Por el camino.

73 AGN, Universidad, 370, fols. 885-914.

74 AGN, Universidad, 264, fols. 607-628.

75 AGN, Bienes Nacionales, leg. 813, exp. 6; leg. 71, exp. 21.
} 
pal que finalizaba. No obstante, Rodríguez Navarijo ya no fue capaz de reconstruir poderes pasados, al punto que con la llegada del nuevo arzobispo Manuel Rubio Salinas fue desplazado otra vez de la curia, siguió sin ascender en el cabildo, al igual que sus sobrinos en sus respectivas carreras, y murió pocos años después, hacia 1757.

\section{Conclusiones}

La clerecía del arzobispado de México era numerosa, compleja y su élite era heredera de un conjunto de tradiciones y prácticas políticas que la hacían sensible a la actitud guardada por cada nuevo arzobispo y por el rey, con respecto a su promoción. La carrera eclesiástica generalmente era larga para quienes la seguían y su éxito dependía de varios factores: políticas reales, políticas de los arzobispos, reafirmación de modelos de carrera antecedentes y de la eficacia de grupos clericales de presión. Este último factor ha constituido el centro de atención del presente trabajo.

Considero que la principal conclusión es que el acceso de los clérigos a los diferentes cargos no puede entenderse de una forma mecánica ni lineal, sino que cada nombramiento estaba en función de las relaciones previas con quien lo otorgaba y de la pertenencia o no a diferentes grupos de origen familiar, de amistad o propiamente clientelares. Así, el cargo de abogado de la ciudad otorgado a Torres Vergara no se le dio por él mismo sino por ser hijo del regidor Juan de Torres; igualmente, cuando gana las máximas cátedras en la universidad, Torres no era cualquier aspirante, sino el juez de testamentos y “doméstico” del arzobispo.

Fue clara la estrategia de Torres de integrarse a colectivos y grupos que lo apoyaran en su trayectoria, e igualmente se convirtió en protector de otros clérigos. Así, su estrategia familiar consistió -aparte de asegurar la manutención y los recursos a los sobrinos para educarse e iniciar una carrera eclesiástica mediante la fundación de capellanías- en facilitar a su pariente favorito, Rodríguez Navarijo, la integración a sus mismos círculos. Torres formó primero un grupo familiar, después uno de amistades y parientes, y juntos acabaron por integrarse como clientela de los capitulares dirigentes del cabildo catedralicio.

La eficacia de tales estrategias tuvo sus altibajos, sobre todo en las coyunturas del cambio de sede plena a vacante o viceversa. La cercanía o lejanía con el arzobispo o con el grupo dirigente del cabildo en turno nos ayuda a explicar nuevos ascensos o estancamientos de las carreras eclesiásticas. Así lo reflejan las trayectorias de Torres y su sobrino. En el caso del primero sus buenas relaciones tanto con el cabildo como con los arzobispos se tradujeron en un encumbramiento que ya divisaba alguna mitra, truncado por la muerte. En el caso del segundo, su carrera dependió bastante del tío, y aun cuando consiguió el apoyo de los dignatarios del cabildo para ascender a maestrescuela, durante la sede vacante de 1728-1730, no pudo lograr nada más durante el gobierno de los dos arzobispos siguientes, hábiles en dividir los intereses del cabildo y crear su propia clientela criolla. 
Los casos aquí estudiados son apenas una primera aproximación a la problemática de construir una historia sociopolítica del clero novohispano en el período colonial intermedio, previo a las reformas borbónicas, pues es necesario profundizar en el conocimiento histórico de los grupos clericales dada su innegable importancia en la vida social y política de la época.

\section{Bibliografía}

\section{Fuentes primarias}

Archivo General de Indias. Sevilla, España.

Archivo General de la Nación. México, México.

\section{Fuentes secundarias}

Aguirre Salvador, Rodolfo. Por el camino de las letras. El ascenso profesional de los catedráticos juristas de la Nueva España. Siglo XVIII. México: Centro de Estudios sobre la Universidad; UNAM, 1998.

. "El ascenso de los clérigos de Nueva España durante el gobierno del arzobispo José Lanciego y Eguilaz”. En Estudios de historia novohispana. T. 22: 77-110. México: Instituto de Investigaciones Históricas; UNAM.

. "El perfil de una élite académica en la Nueva España del siglo XVIII: los licenciados y doctores canonistas”. En Universitarios en Nueva España. Coord. Armando Pavón Romero, 85-150. México: Centro de Estudios sobre la Universidad; UNAM, 2003.

. “AAbogados o clérigos? Una disyuntiva de los juristas en la Nueva España del siglo XVIII”. En Universitarios en Nueva España. Coord. Armando Pavón Romero, 51-84. México: Centro de Estudios sobre la Universidad; UNAM, 2003.

. El mérito y la estrategia. Clérigos, juristas y médicos en Nueva España. México: CESU; Plaza y Valdés, 2003.

. "Los caciques en las instituciones coloniales del período colonial tardío. Una primera aproximación". En Actas del coloquio "Los derechos del hombre desde una perspectiva histórico-jurídica. 1808-1917”. México: UNAM. En prensa.

Brading, David A. Una Iglesia asediada: el obispado de Michoacán, 1749-1810. México: Fondo de Cultura Económica, 1994. 
Castorena y Ursúa, Juan Ignacio y Francisco Sahagún Arevalo. Gacetas de México. México: Secretaría de Educación Pública, 1949-1950.

Chacón Jiménez, Francisco. "Estructuración social y relaciones familiares en los grupos de poder castellanos en el antiguo régimen. Aproximación a una teoría y un método de trabajo”. En La pluma, la mitra y la espada. Estudios de historia institucional en la Edad Moderna. Eds. Juan Luis Castellano, Jean Pierre Dedieu y María Victoria López-Cordón, 355-362. Madrid: Universidad de Burdeos-Marcial Pons, 2000.

Chocano, Magdalena. La fortaleza docta. Élite letrada y dominación social en México colonial (siglos XVI-XVII). Barcelona: Bellaterra, 2000.

Enríquez Agrazar, Lucrecia. "Vacancias eclesiásticas y ascenso social en Chile en el siglo XVIII". En Memoria del 51 Congreso Internacional de Americanistas. CD-ROM. Santiago: Universidad de Chile, 2003.

Faust, Katherine. "Las redes sociales en las ciencias sociales y del comportamiento”. En Análisis de redes. Aplicaciones en ciencias sociales. Eds. Jorge Gil Mendieta y Samuel Schmidt. México: Iimas; UNAM, 2002.

Ganster, Paul. "La familia Gómez de Cervantes. Linaje y sociedad en el México colonial”. Historia Mexicana, No. 122 (octubre-diciembre 1981).

- "Miembros de los cabildos eclesiásticos y sus familias en Lima y la ciudad de México en el siglo XVIII”. En Familias novohispanas. Siglos XVI al XIX. Coord. Pilar Gonzalbo. México: El Colegio de México, 1991.

González, Enrique. “Legislación y poderes en la universidad colonial de México (15511668)”. Tesis doctoral, Universidad de Valencia, 1990.

. "Mecenazgo y literatura. Los destinos dispares de Juan de Narváez y Siguenza y Góngora”. En Carrera, linaje y patronazgo. Clérigos y juristas en Nueva España, Chile y Perú (siglos XVI-XVIII). Coord. Rodolfo Aguirre. México: Centro de Estudios sobre la Universidad; Plaza y Valdés, 2004.

Icaza Dufour, Francisco de. La abogacía en el reino de Nueva España 15211821. México: Miguel Ángel Porrúa, 1998.

Lavrin, Asunción. "La congregación de San Pedro - una cofradía urbana del México colonial-1604-1730”. Historia Mexicana XXIX, No. 4 (1980): 562-601. 
Martínez López-Cano, Pilar; Gisela von Wobeser y Juan Guillermo Muñoz. Cofradías, capellanías y obras pías en la América colonial. México: Instituto de Investigaciones Históricas; UNAM, 1998.

Mazín, Óscar. El cabildo catedral de Valladolid de Michoacán. México: El Colegio de Michoacán, 2000.

Oropeza, Gabriela. “Las actas del cabildo de la catedral de México, 1637-1644”. Tesis de licenciatura en Historia, UNAM, 2004.

Pazos Pazos, María Luisa J. El ayuntamiento de la ciudad de México en el siglo XVII: continuidad institucional y cambio social. Sevilla: Diputación de Sevilla, 1999.

Pérez Puente, Leticia. Universidad de doctores. México: Centro de Estudios sobre la Universidad; UNAM, 2000.

Wobeser, Gisela von. El crédito eclesiástico en la Nueva España. Siglo XVIII. México: Instituto de Investigaciones Históricas; UNAM, 1994. 